Journal of Clinical Investigation

l'ol. 41, No. 5, 1962

\title{
IMMUNOREACTIONS INVOLVING PLATELETS. VI. REACTIONS OF MATERNAL ISOANTIBODIES RESPONSIBLE FOR NEONATAL PURPURA. DIFFERENTIATION OF A SECOND PLATELET ANTIGEN SYSTEM *
}

\author{
By N. RAPHAEL SHULMAN, RICHARD H. ASTER, HOWARD A. PEARSON AND \\ MERILYN C. HILLER \\ (From the National Institute of Arthritis and Metabolic Diseases, and the U. S. Naval Medical \\ Center, Bethesda, Md.)
}

(Submitted for publication November 1, 1961 ; accepted December 17, 1961)

Although there is some evidence that neonatal thrombocytopenic purpura, which occurs in otherwise normal children born of healthy mothers, is caused by maternal antibodies formed against fetal platelets (1-3), lack of reliable serologic techniques generally has prevented convincing demonstration of the responsible antibodies and has precluded thorough investigation of the properties and inheritance of specific platelet antigens presumed to be involved. Because experience in this laboratory has shown that complement fixation is the most sensitive technique for detecting several different types of antiplatelet antibodies (4-6), this technique was applied in a search for antibodies in the sera of normal mothers who had given birth to thrombocytopenic infants. In the present report the isoantibodies which were found are characterized, and the sensitivity of the complement fixation technique is compared with that of other techniques employed in attempts to detect antiplatelet antibodies.

A well defined platelet antigen system recently has been identified $(6,7)$ and the nature of the antigen, its reactions with antibody, and its mode of inheritance have been described in detail (6). One of the maternal isoantibodies studied in the present work permitted differentiation of a second platelet antigen. The properties of the new antigen are compared with those of the previously described antigen.

\section{CASE REPORTS}

Sera of four mothers, who had given birth to six children with neonatal purpura, were tested for anti-

* Part of this work was presented at the Meeting of the American Federation for Clinical Research, April 30, 1961, and appeared as an abstract in Clin. Res. 1961, 9, 157. body. All children were born at full term by normal spontaneous delivery; all developed petechiae and ecchymoses within 1 to 6 hours after birth and had severe thrombocytopenia, but their hemoglobin and leukocyte counts were normal and they had no other congenital defects. The four mothers were in good health, had normal platelet levels shortly after parturition, and had no past history of having idiopathic thrombocytopenic purpura or of receiving blood transfusions. All of the infants recovered as described in the following individual case reports; and, thereafter, none had recurrence of thrombocytopenia during follow-up periods ranging from 3 months to 9 years.

Family $H$. A boy, born to a para I gravida II mother, had a platelet count of 12,000 per $\mathrm{mm}^{3} 2$ hours after birth. Cortisone, $40 \mathrm{mg}$ daily, was given for 8 days, then reduced to $10 \mathrm{mg}$ over a 4-day period. Platelets rose rapidly to 180,000 per $\mathrm{mm}^{3}$ on the third day and skin lesions disappeared in 5 to 6 days. Another son, born 1 year earlier, had had a large ecchymosis at birth covering most of the lower part of his body. His platelet count was 5,000 per $\mathrm{mm}^{3}$ on the day of birth, 25,000 after 3 days, 70,000 after 12 days, 160,000 after 15 days, and normal thereafter. Purpura persisted for 8 days and was accompanied by gross hematuria during the first week.

Family $K$. A girl, born to a para IV gravida IX mother, had fewer than 50,000 platelets per $\mathrm{mm}^{3} 1$ hour after birth. Although no steroid therapy was given, her platelets rose rapidly to normal levels within 4 days, during which time purpura cleared. A sister, 9 years older, developed severe purpura on the first day of life and at the time was found to have "very low" platelets. She had hemorrhagic manifestations for 8 days and required two blood transfusions; but within 14 days her platelets had reached normal levels, and within 3 weeks purpura had disappeared. The mother of Baby $\mathrm{K}$ had had four miscarriages at 3 to 5 months' gestation between the birth of her second and fifth children.

Family $C$. A boy, born to a para 0 gravida I mother, had 8,000 platelets per $\mathrm{mm}^{3}$ and a strongly positive tourniquet test 6 hours after birth. Tibial bone marrow aspiration done on the day of birth showed almost total absence of megakaryocytes. Daily treatment with prednisone, $10 \mathrm{mg}$ intramuscularly, was begun immediately. Platelets rose to 80,000 per $\mathrm{mm}^{3}$ by the fourth day and 
then rose more gradually to 200,000 over the next 2 weeks. Marrow obtained on the tenth day showed a normal number of megakaryocytes.

Family $S$. A girl, born to a para III gravida IV mother, was found to have only an "occasional" platelet on a blood smear taken several hours after birth. She was treated with cortisone, $10 \mathrm{mg}$ daily. Petechiae and ecchymosis gradually disappeared and platelets remained "very low" during the first week of life. Steroid therapy was discontinued after 8 days. Platelets rose gradually to normal levels during the second and third weeks. Bone marrow obtained on the third day of life was normiol, showing an adequate number of megakaryocytes.

\section{MATERIALS AND METHODS}

Methods of preparing platelet suspensions, counting platelets, measuring platelet agglutination, complement fixation, inhibition of clot retraction, and nitrogen content of platelet suspensions; treating platelets with trypsin; and performing antihuman globulin consumption tests were as described in previous studies of platelet immune systems (4-6). Platelet suspensions generally were standardized on the basis of $\mathrm{N}$ content, $800 \pm 50 \mu \mathrm{g} \mathrm{N}$ per $\mathrm{m} 1$ being equivalent to $2 \times 10^{6}$ platelets per $\mathrm{mm}^{3}(6)$.

Complement $\left(\mathrm{C}^{\prime}\right)$ activity was measured in terms of a 50 per cent hemolytic unit (4), with a single hemolysin preparation and erythrocytes from a single sheep. With the antigen systems studied in this report, the maximal amount of fixation occurred within 1 hour at $37^{\circ} \mathrm{C}$. $\mathrm{C}^{\prime}$ fixation was not potentiated by the use of buffers containing calcium and magnesium ions. In all reaction mixtures sufficient $C^{\prime}$ was added so that less than 75 per cent would be fixed. Under these conditions the amount of $C^{\prime}$ fixed was independent of the amount of $C^{\prime}$ initially present (4).

Additional platelet agglutination tests were performed according to the methods described by Dausset (8), and Stefanini (9) and Harrington (1) and their co-workers, and the mixed antiglobulin test was done according to Chalmers, Coombs, Gurner and Dausset (10). The tanned red cell agglutination test for antiplatelet antibodies was performed as described by Kissmeyer-Nielsen (11).

Antibody which was used to phenotype platelets in a previously described platelet antigen system was obtained from a patient who had developed the antibody after blood transfusion (6). Methods of measuring this antibody quantitatively and the definition of an antibody unit are given in a previous paper (6), and the antigen which the antibody identified was labeled $\mathrm{PI}^{\mathrm{A1}}$. The rationale for the system of nomenclature used to describe the three phenotypes and genotypes that were recognized was presented. It was shown in the $\mathrm{P}^{\mathrm{A1}}$-anti-P1 ${ }^{\mathbf{\Lambda 1}}$ system that platelets from some individuals fix twice as much $C^{\prime}$ per platelet as do platelets from other individuals. Family studies indicated that the doubly reactive platelets were from individuals homozygous for the gene determining the $\mathrm{Pl}^{\Delta 1}$ antigen [phenotype $\mathrm{Pl}^{\Delta}(1,1)$ ], while less reactive platelets were from the individuals heterozygous for that gene [phenotype $\left.\mathrm{P}^{\Delta}(1,-)\right]$. Moreover, it was found that platelets from homozygous individuals adsorbed twice as much antibody per platelet as did platelets from heterozygous individuals. Nonreactive platelets were from individuals lacking the gene [phenotype $\left.\mathrm{Pl}^{\boldsymbol{\Lambda}}(-,-)\right]$. These methods of phenotyping platelets are used in the present work with a maternal isoantibody that identifies a new platelet antigen (see Experimental Results, section 2).

\section{EXPERIMENTAL RESULTS}

1. Demonstration of maternal-fetal incompatibility in the $\mathrm{Pl}^{\mathrm{A} 1}$ antigen system. The mother of Family $\mathrm{H}$ had had two thrombocytopenic infants, but serum obtained from her 1 year after the birth of her last child did not contain antibody when we tested it with the father's platelets, using $C^{\prime}$ fixation and agglutination techniques at the limit of their sensitivity for detecting known antiplatelet antibodies (4-6). However, when platelets from the mother, father, and second child were typed with anti-P1 ${ }^{\mathbf{A 1}}$, the mother was found to be a nonreactor, the father homozygous for $P^{\mathrm{A} 1}$, and the child heterozygous for $P l^{\mathbf{A} 1}$ (Figure 1). Therefore, maternal-fetal incompatibility in the $\mathrm{Pl}^{\mathrm{A} 1}$ antigen system was established. Since less than 2 per cent of the individuals in the general population have platelets lacking $\mathrm{P}^{\mathrm{A} 1}$ antigen (6), the probability that neonatal purpura was associated by chance with incompatibility in the $\mathrm{P}^{\mathrm{A} 1}$ system was slight.

Serum from the mother of Family K, obtained 1 day after the birth of her last thrombocytopenic infant, showed no activity with the father's platelets in the usual $\mathrm{C}^{\prime}$ fixation and direct agglutination
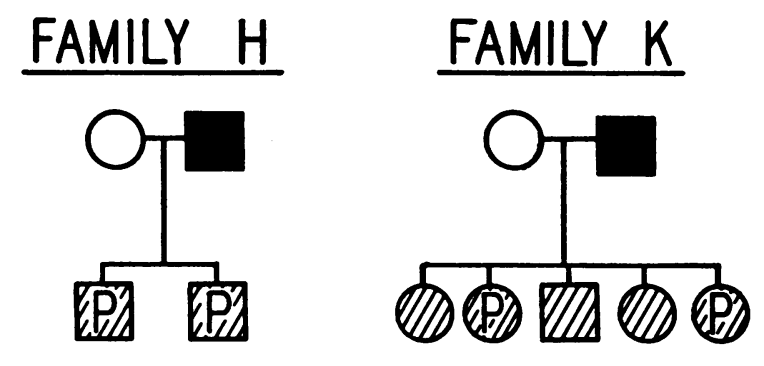

Fig. 1. Platelet types of Families $H$ and $\mathrm{K}$ deTERMINED With ANTI-PL ${ }^{\Delta 1}$ Antibody. Circles indicate females; squares, males. Solid symbols denote individuals homozygous for $P l^{\Delta 1}$ [phenotype $\left.\mathrm{Pl}^{\mathbf{\Delta}}(1,1)\right]$; hatched symbols, heterozygous individuals [phenotype $\left.\mathrm{Pl}^{\mathbf{\Lambda}}(1,-)\right]$; open symbols, nonreactors [phenotype $\left.\mathrm{P}^{\Delta}(-,-)\right]$. Children who had neonatal thrombocytopenic purpura are designated "P." 
tests. However, when platelets from this family were phenotyped with anti-P1 ${ }^{\mathbf{A} 1}$, again there was maternal-fetal incompatibility in the $\mathrm{P}^{\mathrm{A}_{1}}$ antigen system (Figure 1). In view of the infrequency of $\mathrm{Pl}^{\mathrm{A} 1}$-negative individuals (less than 2 per cent), the probability that this incompatibility would occur in two successive families by chance alone was less than 0.0004 . Therefore, the possibility was considered that the serum of Mother $\mathrm{K}$ might contain a non- $\mathrm{C}^{\prime}$-fixing, nonagglutinating antibody which, nevertheless, might interfere with activity of the known anti-P1 ${ }^{\mathrm{A} 1}$ in a manner analogous to that of "blocking" antibodies which develop against erythrocyte antigens. Table I shows the type of experiment used to demonstrate a factor in the serum of Mother $\mathrm{K}$ which interfered with $\mathrm{C}^{\prime}$ fixation by anti-P1 ${ }^{\mathbf{A}}$. Prior incubation of platelets containing the $\mathrm{Pl}^{\mathrm{A} 1}$ antigen with the serum from Mother $\mathrm{K}$ markedly reduced the amount of $\mathrm{C}^{\prime}$ fixed by those platelets in the presence of anti-P1 ${ }^{\mathrm{A} 1}$. When the order of addition was reversed, and the $\mathrm{C}^{\prime}$-fixing anti-P1 ${ }^{\mathrm{A} 1}$ was added to platelets first, interference with $C^{\prime}$ fixation was much less. Interference with $C^{\prime}$ fixation appeared to be specific for the $\mathrm{P}^{\mathrm{A} 1}$-anti-P1 ${ }^{\mathrm{A} 1}$ system, for 75 per cent of the interfering factor could be removed from $2 \mathrm{ml}$ of Mother K's serum by adsorption with $10^{9}$ platelets of phenotype $\mathrm{Pl}^{\boldsymbol{A}}(1,1)$, but it remained unchanged after adsorption with the same number of $\mathrm{Pl}^{\mathrm{A}}(-,-)$ platelets. Moreover, when platelets containing $\mathrm{Pl}^{\mathrm{A} 1}$ were incubated in the serum of Mother $\mathrm{K}$, centrifuged, washed once in 0.85 per cent $\mathrm{NaCl}$, and resuspended, they remained incapable of fixing $\mathrm{C}^{\prime}$ with anti-P1 ${ }^{\mathbf{A}}$. Furthermore, Mother K's serum did not interfere with the $\mathrm{C}^{\prime}$-fixing activity of

TABLE I

Interference with $C^{\prime}$ fixation by serum from Mother $K$ *

\begin{tabular}{|c|c|c|}
\hline $\begin{array}{c}1 \\
\text { Prior incubation }\end{array}$ & $\begin{array}{c}2 \\
\text { Later addition }\end{array}$ & $\begin{array}{c}3 \\
\text { Units } C^{\prime} \\
\text { fixed }\end{array}$ \\
\hline Mother's serum +platelets & Anti-PIA1 $+C^{\prime}$ & 0.5 \\
\hline Normal serum +platelets & Anti-P1 ${ }^{A 1}+C^{\prime}$ & 6.0 \\
\hline Anti-PIA1 +platelets & Mother's serum $+C^{\prime}$ & 2.8 \\
\hline Platelets & Mother's serum $+C^{\prime}$ & $\mathbf{0}$ \\
\hline Anti-Pl ${ }^{\mathrm{A}_{1}}+$ platelets & $\mathrm{C}^{\prime}$ & 5.4 \\
\hline
\end{tabular}

* Reagents in column 1 were incubated for 5 minutes at $37^{\circ} \mathrm{C}$, followed by addition of reagents in column 2 and incubation for 1 hour at $37^{\circ} \mathrm{C}$. Platelets, type $\mathrm{Pl}^{\mathrm{A}}(1,1)(6)$ at $2.5 \times 10^{4}$ per $\mathrm{mm}^{3}$ final concentra-
tion, 5 U of anti-PIA1 (6), and $0.1 \mathrm{ml}$ of serum from Mother $\mathrm{K}$ were used in the various mixtures, the final volume in each tube being $0.4 \mathrm{ml}$, adin the various mixtures, the final
justed with 0.85 per cent $\mathrm{NaCl}$. an isoantibody directed against a platelet antigen which differs (see below) from $\mathrm{Pl}^{\mathrm{A} 1}$.

The antiglobulin consumption test, using Mother K's serum alone, was consistently but weakly positive with $\operatorname{Pl}^{\mathrm{A}}(1,1)$ platelets, but negative with $\mathrm{Pl}^{\mathbf{A}}(-,-)$ platelets. The amount of antiglobulin consumed by $\mathrm{Pl}^{\mathbf{A}}(1,1)$ platelets exposed to Mother K's serum was similar to the amount consumed by the same number of $\mathrm{Pl}^{\mathrm{A}}(1,1)$ platelets saturated with the $\mathrm{C}^{\prime}$-fixing anti-P1 ${ }^{\mathrm{A} 1}(6)$.

The titer of the interfering factor in Mother K's serum could be estimated by determining the smallest amount of serum that would inhibit $\mathrm{C}^{\prime}$ fixation by a given amount of anti- $\mathrm{Pl}^{\mathbf{A}}$, with a given number of platelets. For instance, as little as $0.04 \mathrm{ml}$ of Mother K's serum completely prevented $\mathrm{C}^{\prime}$ fixation by $10^{7} \mathrm{Pl}^{\mathrm{A}}(1,1)$ platelets with $4 \mathrm{U}$ of anti- $\mathrm{Pl}^{\mathrm{A} 1}$ in a $0.4-\mathrm{ml}$ total volume. By this method of titration, no significant decrease in activity was found in Mother K's serum during the first 2 months after delivery. Mother H's serum showed no ability to interfere with $\mathrm{C}^{\prime}$ fixation by anti-P1 ${ }^{\mathbf{A} 1}$, but her serum had been obtained 1 year after the birth of her last child.

2. Demonstration of maternal-fetal incompatibility in a new platelet antigen system. Serum from the mothers of Families C and S, when tested with platelets from both fathers in mixtures similar to those used with anti-P1 ${ }^{\mathrm{A} 1}(6)$, produced $\mathrm{C}^{\prime}$ fixation, as shown in Figure 2. Platelets from both mothers gave no $C^{\prime}$ fixation with their own or each other's serum, whereas platelets obtained from the affected babies, after they had recovered, reacted with serum from both mothers in a manner identical with that of platelets from the fathers.

The factor in the mothers' sera that produced $\mathrm{C}^{\prime}$ fixation is referred to as an antibody because it was found to be nondialyzable, was recovered quantitatively in a fraction of serum precipitated at one-third saturation with ammonium sulfate, and did not lose more than 10 per cent activity on heating for 2 hours at $56^{\circ} \mathrm{C}$ or after storage for at least 6 months at $-20^{\circ} \mathrm{C}$ but was rapidly destroyed when heated at $70^{\circ} \mathrm{C}$.

With the standard curve shown in Figure 2, antibody activity in different serum samples could be compared by the amounts of sera required to produce a given amount of $C^{\prime}$ fixation in the presence of excess antigen $(4,6)$. With any one serum sample the standard curve was reproducible 
from day to day with an error of \pm 10 per cent, provided freshly prepared platelets were used. One unit of antibody activity was defined arbitrarily as that amount required to fix $4 \mathrm{U}$ of $\mathrm{C}^{\prime}$ under conditions shown in Figure 2. The serum sample used in this figure, obtained 1 week post partum from Mother C, contained $29 \pm 2.9$ antibody $\mathrm{U}$ per $\mathrm{ml}$. Antibody activity in Mother C's serum, measured by this method, remained unchanged for approximately 2 months, then decayed gradually to 50 per cent of the initial value within the subsequent 2 months. The serum of Mother $\mathrm{S}$ contained $20 \mathrm{U}$ of antibody per $\mathrm{ml} 4$ years after the birth of her last thrombocytopenic infant, and antibody activity in her serum from the postpartum period contained $25 \mathrm{U}$ per $\mathrm{ml}$, after frozen storage for 4 years. The frozen serum was the only sample available on Mother $\mathrm{S}$ from the postpartum period.

Serum from the infant of Mother C was the only infant's serum available from the neonatal period. The infant's serum obtained on the first day of life contained antibody, but the titer was approximately one-tenth that of the mother's serum obtained on the same day.

Sera from 37 mothers of unknown platelet type, obtained at the time they delivered, were used in $\mathrm{C}^{\prime}$ fixation tests with platelets known to react with the sera from Mothers $\mathrm{C}$ and $\mathrm{S}$. These sera were used at one-half dilution with platelets at concentrations of both 50,000 and 300,000 per $\mathrm{mm}^{3}$. None of the sera fixed $\mathrm{C}^{\prime}$. Previous pregnancies included, the mothers tested had given birth to a total of 90 normal children.

The following observations show that the antibodies in sera of Mothers $\mathrm{C}$ and $\mathrm{S}$ had identical specificity for an antigen which differs from $\mathrm{Pl}^{\mathrm{A} 1}$. Both mothers' sera were tested against platelets from 49 normal individuals selected at random. For these tests $2.3 \mathrm{U}$ of antibody and a final platelet concentration of $2.5 \times 10^{5}$ per $\mathrm{mm}^{3}$ were used in mixtures otherwise as in the legend of Figure 2. The specificity of reactions with sera from both mothers was identical, $\mathrm{C}^{\prime}$ fixation being obtained with platelets from 39 per cent of the donors. This frequency of positive reactors is in contrast to the positive reactors of greater than 98 per cent found with anti-P1 ${ }^{\mathbf{A}}$. The platelet antigen identified by antibody in serum from Mothers $\mathrm{C}$ and $\mathrm{S}$ was different from the $\mathrm{PI}^{\mathrm{A} 1}$ platelet antigen, as well as from erythrocyte antigens $A_{1}, A_{2}, O, B$, M, N, S, P, C, D, E, c, e, D ${ }^{\mathrm{u}}, \mathrm{K}, \mathrm{Fy}^{\mathrm{a}}$, Le $\mathrm{Le}^{\mathrm{a}}$ and $\mathrm{Le}^{\mathrm{b}}$, based on platelet and erythrocyte phenotypes determined on 22 individuals. The new platelet antigen will be referred to as $\mathrm{Pl}^{\mathrm{B} 1}$ for reasons discussed previously (6). Anti- $\mathrm{Pl}^{\mathrm{B} 1}$ could not be demonstrated in sera from 12 normal $P l^{\mathrm{B}}(-,-)$ individuals by $\mathrm{C}^{\prime}$ fixation or agglutination techniques.

As with the $P 1^{\mathrm{A} 1}$ platelet antigen (see Materials and Methods), the amount of $\mathrm{Pl}^{\mathrm{B} 1}$ antigen per platelet could be determined by the amount of $\mathrm{C}^{\prime}$ fixed per platelet and by the amount of antibody adsorbed per platelet in the presence of excess antibody. Figure 3 shows the amount of $C^{\prime}$ fixed by platelets from two different reactive donors. With previously described methods for measuring antibody adsorption (6), the platelets used to obtain curve 1, Figure 3, adsorbed approximately twice as much antibody per platelet as did the platelets used to obtain curve 2, Figure 3. By inference

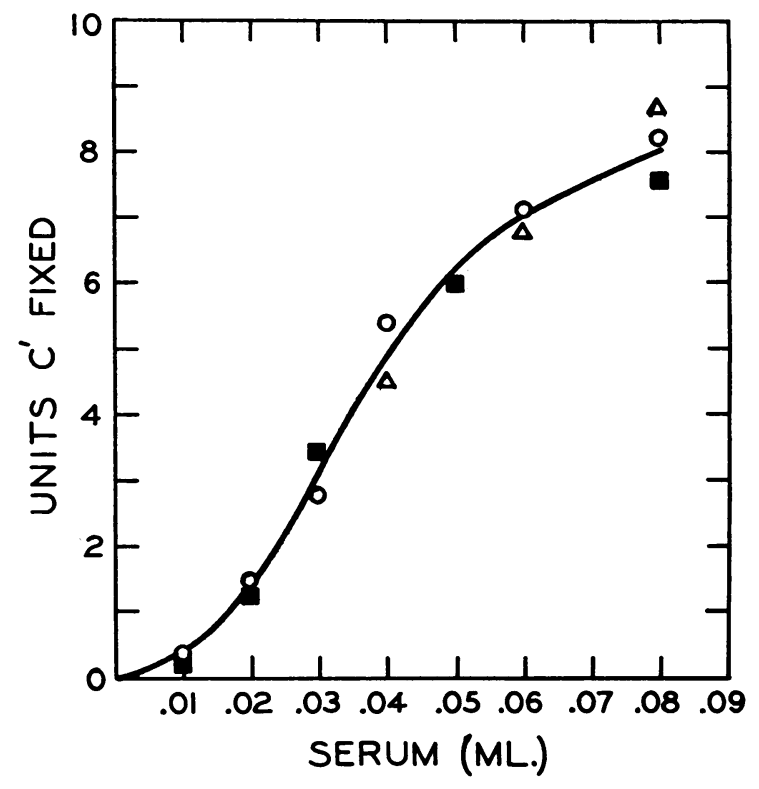

Fig. 2. Standard curve of C' fixation with Sera From Mothers C AND S. Various amounts of serum, indicated on the abscissa, were incubated with platelets (final concentration $3 \times 10^{5}$ per $\mathrm{mm}^{3}$ ) for 1 hour at $37^{\circ} \mathrm{C}$ in the presence of guinea pig $\mathrm{C}^{\prime}$ before residual $\mathrm{C}^{\prime}$ was measured. Total volume of incubation mixture was 0.4 $\mathrm{ml}$. Each symbol indicates an experiment done on a different day, using a different platelet preparation. One serum sample from Mother $\mathrm{C}$ was used throughout and all platelets used were phenotype $\mathrm{Pl}^{\mathrm{B}}(1,-)$ (see text). Serum from Mother $S$ gave an identical curve, but different amounts of serum were required (see text). 
from knowledge of the $\mathrm{Pl}^{\mathbf{A} 1}$-antigen system, it appeared that platelets doubly reactive with anti- $\mathrm{Pl}^{\mathbf{B} 1}$ were from individuals homozygous for $\mathrm{Pl}^{\mathrm{B}_{1}}$, and that less reactive platelets were from individuals heterozygous for $\mathrm{Pl}^{\mathrm{B} 1}$. Platelets from only one of the positive reactors tested thus far have been doubly reactive. However, since positive reactors account for 39 per cent of the population tested, only approximately 4.8 per cent of the population would be expected (12) to be homozygous for the $P l^{\mathbf{B} 1}$ gene. Further evidence that less reactive platelets represent the heterozygous state in the $\mathrm{P}^{\mathrm{B} 1}$ antigen system was obtained from the frequency of nonreactive platelets in offspring of matings between nonreactive individuals and individuals presumed to be heterozygous for the $P l^{\mathrm{B} 1}$ gene, on the basis of $\mathrm{C}^{\prime}$ fixation tests done as in Figure 3. Of the 15 offspring tested, 8 were nonreactive with anti- $\mathrm{Pl}^{\mathrm{B} 1}$, and platelets from those who were reactive fixed $C^{\prime}$ quantitatively in the same manner as did platelets from the reactive parent. This is consistent with the expected 50-50 distribution of the $P l^{\mathrm{B} 1}$ gene if the $\mathrm{Pl}^{\mathrm{B} 1}$-positive parent were, in fact, heterozygous. Phenotypes of Families $\mathrm{C}$ and $\mathrm{S}$ in the $\mathrm{Pl}^{\mathrm{B} 1}$ system are shown in Figure 4 ; in Table II the observed frequency of the three possible phenotypes of the $\mathrm{Pl}^{\mathrm{B} 1}$ system are compared with those of the $\mathrm{Pl}^{\mathrm{A} 1}$ system.

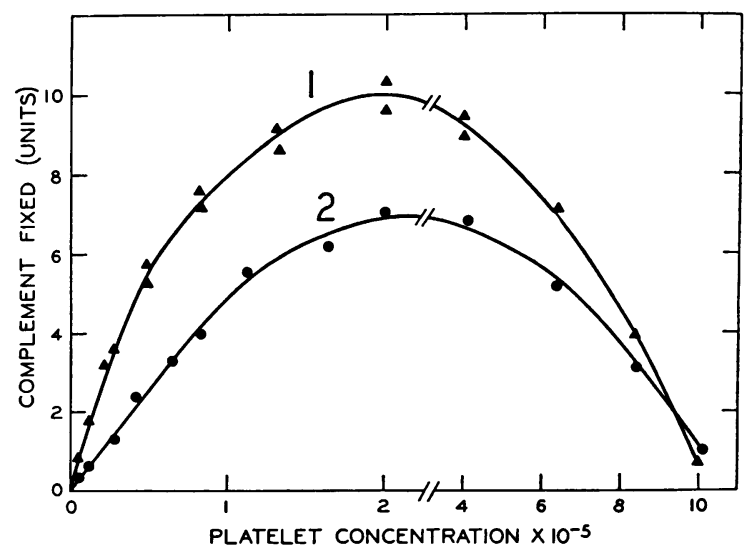

Fig. 3. C' Fixation with VARIOUS Platelet CONCENTRATIONS AND A FIXED CONCENTRATION OF ANTI-P1 ${ }^{B 1}$. Incubation mixtures contained $0.06 \mathrm{ml}$ of the same serum used in Fig. 2 and various concentrations of platelets indicated on the abscissa. Conditions otherwise as in Fig. 2. Curve 1 was obtained with highly reactive platelets from one individual (see text) and curve 2 was obtained with platelets which produced the usual reaction (see text).

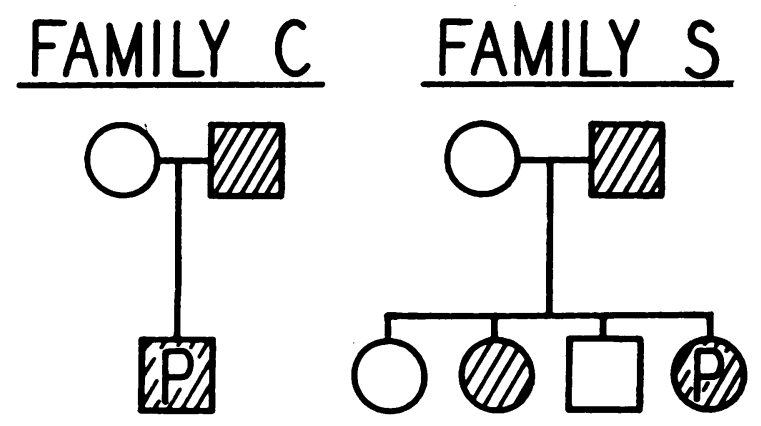

Fig. 4. Platelet types of Families C and S DeterMined With ANTI-PL ${ }^{B 1}$ Antibody. Symbols are as in Fig. 1, hatched symbols representing individuals heterozygous for $P l^{\mathbf{B 1}}$ [phenotype $\left.P 1^{\mathrm{B}}(1,-)\right]$ and open symbols, nonreactors [phenotype $\left.\mathrm{Pl}^{\mathrm{B}}(-,-)\right]$.

Although the frequencies of the two genes, $P l^{\mathbf{A}}$ and $P l^{\mathbf{B} 1}$, are consistent with their being alleles, the following results of phenotyping selected individuals for both antigens indicate that $P l^{\mathbf{B 1}}$ is not an allele of $P l^{\mathbf{A} 1}$. The one individual who was apparently homozygous for $P l^{\mathrm{B} 1}$ was heterozygous for $P l^{\mathbf{A} 1}$; of seven individuals apparently heterozygous for $P l^{\mathbf{B} 1}$, five were homozygous and two were heterozygous for $\mathrm{Pl}^{\mathbf{A} \mathbf{1}}$; and of three $\mathrm{Pl}^{\mathbf{A} 1}$-negative individuals, two were also $\mathrm{Pl}^{\mathrm{B} 1}$-negative and one was apparently heterozygous for $P l^{\mathrm{B} 1}$.

3. Properties of $P l^{B 1}$ antigen and $P l^{B_{1}}$-anti-P $P l^{B 1}$ complex. The $C^{\prime}$-fixing activity of platelets containing $\mathrm{P}^{\mathrm{B} 1}$ antigen was reduced 25 per cent after heating for 10 minutes at $56^{\circ} \mathrm{C}$ and 75 per cent after 45 minutes at $56^{\circ} \mathrm{C}$, but platelets heated in this way retained full ability to adsorb antibody. Platelets heated at $100^{\circ} \mathrm{C}$ for 10 minutes lost all $\mathrm{C}^{\prime}$-fixing activity, as well as the ability to adsorb antibody. Lyophilized platelets reconstituted in 0.85 per cent $\mathrm{NaCl}$ did not fix $\mathrm{C}^{\prime}$ with antibody but adsorbed antibody almost as well as an equivalent number of fresh platelets. Platelets suspended in 0.85 per cent $\mathrm{NaCl}$ lost approximately 50 per cent of their $\mathrm{C}^{\prime}$-fixing activity over a 60-day period at $5^{\circ} \mathrm{C}$, whereas platelets kept frozen at $-20^{\circ} \mathrm{C}$ retained full ability to fix $\mathrm{C}^{\prime}$ and adsorb antibody for at least 2 months.

Platelets exposed to trypsin for 20 minutes lost approximately 50 per cent of their $C^{\prime}$-fixing activity, but more prolonged exposure to trypsin did not result in further loss of activity. By an agar gel diffusion technique, anti- $\mathrm{Pl}^{\mathrm{B} 1}$ did not form a precipitin line with serum from $\mathrm{Pl}^{\mathrm{B} 1}$-positive per- 
TABLE II

Frequency of platelet phenotypes identified by anti-PlB1 *

\begin{tabular}{|c|c|c|c|c|c|}
\hline \multirow[b]{2}{*}{$\begin{array}{l}\text { Probable } \\
\text { genotype }\end{array}$} & \multicolumn{3}{|c|}{$\mathrm{Pl}^{\mathrm{B}}$ system } & \multicolumn{2}{|c|}{$\mathrm{Pl}^{\mathbf{A}}$ system } \\
\hline & $\begin{array}{c}\text { Phenotype } \\
\text { symbol }\end{array}$ & $\begin{array}{l}\text { Number } \\
\text { found }\end{array}$ & Frequency & $\begin{array}{l}\text { Phenotype } \\
\text { symbol }\end{array}$ & Frequency \\
\hline & & & $\%$ & & $\%$ \\
\hline $\begin{array}{l}\text { Homozygous } \\
\text { reactor }\end{array}$ & $\mathrm{Pl}^{\mathrm{B}}(1,1)$ & 1 & 2 & $\mathrm{Pl}^{\mathrm{A}}(1,1)$ & 75.7 \\
\hline $\begin{array}{l}\text { Heterozygous } \\
\text { reactor }\end{array}$ & $\operatorname{Pl}^{\mathrm{B}}(1,-)$ & 18 & 37.5 & $\operatorname{Pl}^{A}(1,-)$ & 22.6 \\
\hline $\begin{array}{l}\text { Homozygous } \\
\text { nonreactor }\end{array}$ & $\mathrm{Pl}^{\mathrm{B}}(-,-)$ & 29 & 60.5 & $\operatorname{Pl}^{\mathbf{A}}(-,-)$ & 1.7 \\
\hline
\end{tabular}

${ }^{*} \mathrm{Pl}^{\mathrm{B} 1}$ antigen per platelet measured as in Figure 3. Individuals whose platelets conformed to curve 2, Figure 3, were considered heterozygous for the $P l^{\mathrm{B} 1}$, while the one individual whose platelets reacted as in curve 1 was considered homozygous for $P l^{\mathrm{B} 1}$. Values for the $\mathrm{Pl}^{\mathrm{A}}$ system are taken from Ref. 6.

sons known to be secretors of $\mathrm{A}, \mathrm{B}$, or $\mathrm{H}$ substance. The $\mathrm{Pl}^{\mathrm{B} 1}$ antigen was not detected on erythrocytes of $\mathrm{Pl}^{\mathbf{B} 1}$-positive individuals, either by $\mathrm{C}^{\prime}$ fixation or adsorption techniques, and was not detected on platelets obtained from eight rabbits, seven dogs, and one sheep.

Some indication of the stability of $\mathrm{Pl}^{\mathrm{B} 1}$-anti- $\mathrm{P} 1^{\mathrm{B} 1}$ complexes was obtained from the following experiments. Platelets saturated with anti-P $1^{\mathrm{B} 1}$ by incubation in excess antibody were subjected to repeated washes in 0.85 per cent $\mathrm{NaCl}$ and tested for their ability to fix $\mathrm{C}^{\prime}$ after each wash, as described in the legend of Figure 5. The $\mathrm{Pl}^{\mathrm{B} 1}$-anti$\mathrm{Pl}^{\mathrm{B} 1}$ complexes [when we used apparent $\mathrm{Pl}^{\mathrm{B}}(1,1)$ or $\mathrm{P}^{\mathrm{B}}(1,-)$ platelets] lost much more $\mathrm{C}^{\prime}$-fixing activity than did $\mathrm{Pl}^{\mathrm{A} 1}$-anti- $\mathrm{P}^{\mathrm{A} \mathbf{1}}$ complexes treated in a similar fashion. Although $\mathrm{Pl}^{\mathrm{A} 1}$-anti- $\mathrm{Pl}^{\mathrm{A} 1} \mathrm{com}-$ plexes were highly resistant to dissociation by various forms of treatment (6), $\mathrm{Pl}^{\mathrm{B} 1}$-anti- $\mathrm{Pl}^{\mathrm{B} 1} \mathrm{com}$ plexes could be reversed as follows : platelets saturated with anti-P1 ${ }^{\mathrm{B} 1}$ were washed once quickly with cold 0.85 per cent $\mathrm{NaCl}$, then suspended in 15 per cent $\mathrm{NaCl}$ and heated at $56^{\circ} \mathrm{C}$ for 30 minutes. The supernatant fluid of heated platelets was tested for antibody activity after dialysis for 16 hours against 0.85 per cent $\mathrm{NaCl}$ at $5^{\circ} \mathrm{C}$. Approximately 20 per cent of the antibody initially adsorbed on platelets was recovered by this technique.

The order of adding antibody, platelets, and $\mathrm{C}^{\prime}$ to reaction mixtures had no effect on the amount of $\mathrm{C}^{\prime}$ fixed by $\mathrm{Pl}^{\mathrm{A} 1}$-anti-P1 ${ }^{\mathrm{A} 1}$ complexes (6); but, as shown in Table III, the amount of $C^{\prime}$ fixed by mixtures of $\mathrm{P}^{\mathrm{B} 1}$ and anti- $\mathrm{Pl}^{\mathrm{B} 1}$ was influenced by the sequence of adding reagents. By comparing results in Table III with results in Figure 2, it is seen that the effect of order of adding reagents on $\mathrm{C}^{\prime}$ fixation was more pronounced when antibody was in relative excess. Thus, much less $C^{\prime}$ was fixed when platelets were preincubated with relatively large amounts of antibody before $C^{\prime}$ was added, than was fixed when $C^{\prime}$ was present in the mixture before antigen and antibody were allowed to interact. The higher the ratio of antibody to platelets, the greater was the discrepancy between the amount of $C^{\prime}$ fixed when $C^{\prime}$ was added first and last, whereas the order of adding $C^{\prime}$ had little or no influence on the amount of $\mathrm{C}^{\prime}$ fixed when antibody was present in relatively small amounts.

4. Serologic techniques other than $C^{\prime}$ fixation used with anti-P $l^{B 1}$. The following tests, frequently used in the study of antiplatelet antibodies, were carried out with serum containing the highest titer of anti-P1 $1^{\mathbf{B} 1}$ and platelets known to be reactive in $\mathrm{C}^{\prime}$ fixation tests with this antibody.

Direct platelet agglutination tests, performed by several methods using twofold serial serum dilutions from $1 / 2$ to $1 / 16$ to avoid a possible prozone effect, did not give agglutination. Weak agglutination was noted frequently with serum concentrations greater than 50 per cent in experimental tubes, but control tubes containing normal sera or platelets nonreactive with anti-P1 ${ }^{\mathrm{B} 1}$ showed the same agglutination. Specific agglutination, therefore, could not be evaluated in mixtures containing greater than 50 per cent serum; and with serum concentrations less than 25 per cent, no agglutination occurred in control or experimental mixtures. 
The mixed antiglobulin test described by Chalmers and co-workers (10) and the indirect Coombs test, performed on platelets exposed to antibody and washed in 0.85 per cent $\mathrm{NaCl}$, did not give specific agglutination. The antiglobulin consumption test gave the same results with platelets which either did or did not react in $\mathrm{C}^{\prime}$ fixation tests with anti-P1 $1^{\mathrm{B} 1}$. The tanned red cell agglutination test (11) gave uniformly negative results, not only with anti-P1 ${ }^{\mathbf{B} 1}$, but also with anti-P1 ${ }^{\mathbf{A} 1}$.

There was no inhibition of clot retraction when

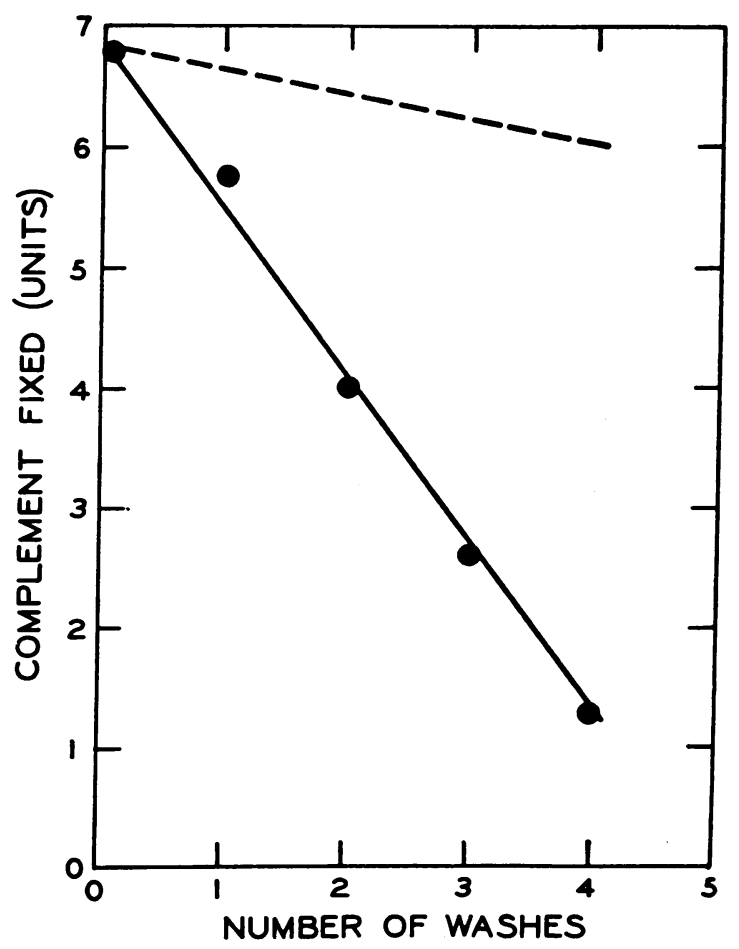

Fig. 5. EFFECT OF REPEATED WASHING ON COMPLEMENT FiXation By PLATELETS SENSITIZED With ANTI- $\mathrm{PL}^{\text {B1 }}$. Four $\mathrm{ml}$ of anti-P1 ${ }^{\mathrm{B} 1}$ serum containing 28 antibody $\mathrm{U}$ per $\mathrm{ml}$ was incubated for 1 hour at $37^{\circ} \mathrm{C}$ with $2 \times 10^{\circ}$ platelets [apparent phenotype $P 1^{B}(1,1)$ ], following which platelets were sedimented at $3,000 \mathrm{G}$ and resuspended in cold 0.85 per cent $\mathrm{NaCl}$ at a concentration of $10^{8}$ per $\mathrm{mm}^{3}$. An aliquot of the resuspended platelets was saved, and the remaining suspension was brought to $3 \mathrm{ml}$ with cold 0.85 per cent $\mathrm{NaCl}$ and centrifuged again. This washing process was repeated 4 times, and after each wash an aliquot of the platelet suspension, containing $2.5 \times 10^{7}$ platelets, was mixed immediately with $12 \mathrm{U}$ of $\mathrm{C}^{\prime}$ in a final volume of $0.4 \mathrm{ml}$. Residual $\mathrm{C}^{\prime}$ was measured after incubation for 60 minutes at $37^{\circ} \mathrm{C}$, and the symbols represent the amount of $\mathrm{C}^{\prime}$ fixed after each wash. The dashed line represents results of a similar experiment done, using platelets sensitized with anti-P1 ${ }^{\Delta 1}(6)$.
TABLE III

Effect of varying order of adding reagents on $C^{\prime}$ fixation *

\begin{tabular}{lcc}
\hline \multicolumn{1}{c}{ Prior incubation } & Later addition & $\begin{array}{c}\text { Units } \mathrm{C}^{\prime} \\
\text { fixed }\end{array}$ \\
\hline 5 U anti-Pl' ${ }^{\mathrm{B} 1}+$ platelets & $\mathrm{C}^{\prime}$ & 3.4 \\
Platelets $+\mathrm{C}^{\prime}$ & $5 \mathrm{U}$ anti-P1 & 6.5 \\
1 U anti-Pl ${ }^{\mathrm{B} 1}+$ platelets & $\mathrm{C}^{\prime}$ & 4.0 \\
Platelets $+\mathrm{C}^{\prime}$ & $1 \mathrm{U}$ anti-P1 & 4.4 \\
\hline
\end{tabular}

* Prior incubation was carried out for 5 minutes at $37^{\circ} \mathrm{C}$; serum was the same as that used in Figure 2; final platelet [apparent phenotype $\mathrm{Pl}^{\mathrm{B}}(1,-)$ ] concentration was $2 \times 10^{5}$ per $\mathrm{mm}^{3}$, and $10 \mathrm{U}$ of $\mathrm{C}^{\prime}$ was used in mixtures which otherwise were as in Figure 2.

serum containing as much as $29 \mathrm{U}$ of anti- $\mathrm{Pl}^{\mathrm{B} 1}$ per $\mathrm{ml}$ was mixed with an equal volume of fresh blood from individuals whose platelets fixed $\mathrm{C}^{\prime}$ with that antibody.

\section{DISCUSSION}

1. Clinical significance. The possibility that maternal isoantibodies can cause neonatal thrombocytopenia has been considered previously (1-3, $13,14)$ but, in general, adequate serological confirmation has been prevented by the lack of satisfactory techniques. Moulinier (3) was the only investigator who attempted to determine the frequency of a platelet antigen in the general population, using serum of a normal mother who had given birth to thrombocytopenic infants. He used the antiglobulin consumption test with papainetreated platelets, had difficulty with false-positive reactions, but concluded that about 22 per cent of platelets selected at random were positive for the antigen involved, which was called "duzo." The mode of inheritance of this antigen was not studied. The present work establishes a genetic basis for maternal-fetal incompatibility in two well defined platelet-antigen systems and describes the nature of the reactions of antibodies that can cause neonatal purpura. In one family, evidence for isoimmune origin of the purpuric disease was based only on the finding of maternal-fetal incompatibility of $\mathrm{P}^{\mathrm{A} \mathbf{1}}$; in another family, on incompatibility of $\mathrm{PI}^{\mathrm{A} 1}$ as well as the presence of a factor in the mother's serum that interfered with $\mathrm{C}^{\prime}$-fixing activity of anti-P1 ${ }^{\Delta \mathbf{A}}$; and in two other families, on the presence of a C'-fixing antibody in the mothers' sera and one infant's serum against a newly recognized antigen, $\mathrm{Pl}^{\mathrm{B} 1}$. 
Since 61 per cent of the population tested lack the $\mathrm{P}^{\mathrm{B}_{1}}$ antigen, and 39 per cent have it, approximately $[0.61 \times 0.39=] 24$ per cent of all marriages are incompatible for this antigen. Fathers who carry the antigen are almost all heterozygous; hence there is an opportunity for maternal immunization by $\mathrm{Pl}^{\mathrm{B} 1}$ in approximately $[1 / 2 \times 24$ per cent $=$ ] 12 per cent of all pregnancies. However, immunization against $\mathrm{Pl}^{\mathrm{B} 1}$ does not appear to occur so frequently as this (see Experimental Results, section 2). The true frequency of isoimmune neonatal thrombocytopenia is not accurately established, for in most of the patients purpuric symptoms subside within a few days to a week (see Case Reports and Refs. 2,15) and the disease might not be diagnosed if a platelet count is not done during the first few days of life. The recent report by Kaplan (16) suggests that neonatal thrombocytopenia is more common than has been thought. Although erythroblastosis is unusual in the first-born child, neonatal purpura occurred in the first-born child in Families $\mathrm{H}$ and $\mathrm{C}$, owing to anti-P1 $1^{\mathbf{A} 1}$ and anti-P1 ${ }^{\mathrm{B} 1}$, respectively. This suggests that platelets may cross the placenta and induce sensitization more easily than do red cells. There may be a number of antigens other than $\mathrm{Pl}^{\mathrm{B}^{1}}$ and $\mathrm{Pl}^{\mathrm{A} 1}$ that may cause maternal isoimmunization.

Because some thrombocytopenic infants born to normal mothers have abundant megakaryocytes in their bone marrow $(1,17)$, while others lack megakaryocytes $(2,15,18)$, neonatal purpura has been classified as megakaryocytic or amegakaryocytic (18), implying difference in etiology. One of the infants in the present report had normal megakarocytes (Family S), and one had virtual absence of megakaryocytes (Family C). Since the same isoantibody, anti-P $1^{\mathrm{B} 1}$, was no doubt responsible for the thrombocytopenia in both cases, there seems to be no good reason to divide the syndrome of neonatal thrombocytopenic purpura arbitrarily into megakaryocytic and amegakaryocytic forms. The fact that megakaryocytes may be absent at birth in isoimmune neonatal purpura, owing to incompatibility of the $\mathrm{Pl}^{\mathrm{B} 1}$ antigen, suggests that this antigen may be present on megakaryocytes or their precursors, but it is not clear as yet why some purpuric infants have adequate megakaryocytes and others do not. In adults the destruction of circulating platelets by other well defined antibodies has not been observed to cause hypoplasia of megakaryocytes $(6,19)$.

Mothers having idiopathic thrombocytopenic purpura (ITP) frequently give birth to thrombocytopenic infants $(1,20)$. It is interesting, with respect to duration of thrombocytopenia, that purpuric infants born of mothers with ITP usually take more than 5 , and up to 16 , weeks to recover $(1,20-26)$, whereas recovery from isoimmune neonatal purpura usually occurs in less than 2 weeks (see Case Reports and Refs. 2, 15). Thus, it appears that the suspected antiplatelet factor of ITP differs from the observed antiplatelet isoantibodies, either in its mode of action or in its ability to be cleared from the infant's circulation. Although ITP has many characteristics of an immunologic disorder, antibody has not been detected in sera of patients with ITP by the general techniques used herein (6); but conceivably ITP could be caused by a "blocking" antibody that is not detectable by direct measurements (see Discussion, Section 3). If the ITP antiplatelet factor is indeed an antibody, the long period of clearance from the infant's circulation may reflect transference of relatively large amounts of antibody across the placenta.

The appropriate form of therapy to be used in cases of isoimmune neonatal purpura is not as yet clear, for effects of steroid hormones, splenectomy, or other forms of treatment on the natural course of the disease cannot be evaluated without regard to the nature and level of the responsible antibody. With recognition and means of measuring different specific antibodies and different types of antibody activity, evaluation of therapy will be simplified. In some instances exchange transfusion may prove to be useful, as it is in erythroblastosis fetalis, for an isoantibody of post-transfusion immunologic purpura has been successfully removed in this way (6). It should be pointed out, however, that administration of platelets that react with a circulating isoantibody may cause severe reactions $(3,6)$.

2. Comparison of the $P l^{A_{1}}$ and $P l^{B_{1}}$ antigens. Just as in the case of the $\mathrm{Pl}^{\mathrm{A1}}$ antigen (6), the $\mathrm{Pl}^{\mathrm{B} 1}$ antigen is inherited as a dominant character and, more specifically, appears to be inherited as a co-dominant character dependent on a gene capable of expressing itself in a single or double dose. No evidence was obtained for free $\mathrm{Pl}^{\mathrm{B} 1}$ antigen 
in serum of individuals who had $\mathrm{Pl}^{\mathrm{B} 1}$-positive platelets, for $\mathrm{Pl}^{\mathrm{B} 1}$ antigen on erythrocytes, or for a naturally occurring anti-P1 ${ }^{\mathrm{B} 1}$. The same was true for $\mathrm{P}^{\mathrm{A} 1}$ antigen. The $\mathrm{P}^{\mathrm{B} 1}$ antigen was distinct from a number of erythrocyte antigens and from the $P 1^{\mathbf{A} 1}$ antigen, and $P l^{\mathbf{B} 1}$ was not inherited as an allele of $P l^{\mathbf{A} 1}$. Some animal platelets containing $\mathrm{Pl}^{\mathrm{A} 1}$ antigen did not contain $\mathrm{Pl}^{\mathrm{B} 1}$ antigen.

Platelets containing $\mathrm{Pl}^{\mathrm{B} 1}$ antigen did not lose their ability to fix $C^{\prime}$ with antibody as readily after heating as did $\mathrm{Pl}^{\mathbf{A} 1}$-positive platelets. Several forms of treatment resulted in loss of the ability of $\mathrm{P}^{\mathrm{B} 1}$-positive platelets to fix $\mathrm{C}^{\prime}$ with anti- $\mathrm{Pl}^{\mathrm{B} 1}$, but not in loss of their ability to adsorb anti-P1 ${ }^{\mathrm{B} 1}$. This has been observed with $\mathrm{Pl}^{\mathrm{A} 1}$-positive platelets as well, and suggests that the $C^{\prime}$-fixation reaction is dependent on factors in addition to antigenantibody combination (4). As in the case of the $\mathrm{P}^{\mathrm{A} 1}$ antigen, the $\mathrm{P}^{\mathrm{B} 1}$ antigen was resistant to denaturation and to inactivation by trypsin, but whether the antigenic material is a polysaccharide or protein remains uncertain.

3. The problem of measuring antiplatelet antibodies. Detection of a factor in Mother K's serum which interfered with $C^{\prime}$ fixation by a known antibody (see Results, section 1) is analogous to detection of the so-called "blocking" antibodies, well known to develop against erythrocyte antigens. In the present work, interference with $C^{\prime}$ fixation, rather than with cellular agglutination, was the basis for detecting what appears to be an immulologically specific nonagglutinating, noncomplement-fixing antibody.

The $\mathrm{C}^{\prime}$-fixing reactions of anti- $\mathrm{Pl}^{\mathrm{B} 1}$ differed in some respects from reactions of other platelet antibodies which have been described $(4,6)$. In assaying anti- $\mathrm{Pl}^{\mathrm{B} 1}$, the general principle of varying platelet concentration to find an optimal range for a given antibody concentration $(4,6)$ applied, but different ranges of platelet concentration were required in assaying anti-P1 ${ }^{\mathrm{B} 1}$ (Figure 3 ) and anti$\mathrm{Pl}^{\mathrm{A} 1}$. This finding indicates that in attempts to detect unknown antiplatelet antibodies by $C^{\prime}$ fixation techniques, platelet concentration in reaction mixtures should be varied over a wide range, at least from 25,000 to 500,000 per $\mathrm{mm}^{3}$. The order of adding reagents markedly influenced the amount of $\mathrm{C}^{\prime}$ fixed by anti-P1 ${ }^{\mathrm{B} 1}$ (see Results, section 3 ), but had no influence on the amount of $C^{\prime}$ fixed by anti-P1 ${ }^{\mathbf{A 1}}(6)$. The significance of this phenom- enon is not clear, but the observation indicates the importance of varying the order of adding reagents to $C^{\prime}$-fixation mixtures when searching for unknown antibodies.

Various techniques other than $C^{\prime}$ fixation applied in attempts to detect anti- $\mathrm{Pl}^{\mathrm{B} 1}$ were unsuccessful (see Results, section 4). We would expect the tanned red cell agglutination tests to be negative in view of the fact that $\mathrm{Pl}^{\mathrm{B} 1}$ antigen is not present in saline extracts of $\mathrm{Pl}^{\mathrm{B} 1}$-positive platelets. The relatively weak association between $\mathrm{Pl}^{\mathrm{B} 1}$ and anti-P1 ${ }^{\mathrm{B} 1}$ (see Results, section 3) may account for negative results with methods that require repeated washing of sensitized platelets, such as the antiglobulin consumption test and the mixed antiglobulin test. By contrast, anti-P1 $1^{\mathrm{A} 1}$, which combines very firmly with antigen, gave a positive antiglobulin consumption test (6). Inability of various direct agglutination techniques and the clot retraction inhibition test to detect anti- $\mathrm{Pl}^{\mathrm{B} 1}$ are observations awaiting explanation, but perhaps failure of these tests also may be related to the instability of $\mathrm{Pl}^{\mathrm{B} 1}$-anti- $\mathrm{Pl}^{\mathrm{B} 1}$ complexes.

The greater sensitivity and versatility of $C^{\prime}$-fixation reactions, compared with other serological tests used with the maternal isoantibodies, parallels observations made on other anti-platelet antibody systems $(4,6,27)$. This indicates that no search for antiplatelet isoantibodies can be considered complete without application of $\mathrm{C}^{\prime}$ fixation tests.

\section{SUMMARY}

1. Maternal immunization against antigens on fetal platelets was found to be the basis of megakaryocytic or amegakaryocytic neonatal thrombocytopenic purpura in six children born of four normal mothers.

2. In two families there was mother-fetal incompatibility with respect to the previously described $\mathrm{Pl}^{\mathrm{A} 1}$ platelet antigen, and in the other families with respect to a newly recognized antigen, $\mathrm{Pl}^{\mathrm{B} 1}$. The mode of inheritance and other properties of $\mathrm{Pl}^{\mathrm{B} 1}$ antigen are described.

3. Complement fixation proved to be the only serologic technique by which anti- $\mathrm{Pl}^{\mathrm{B} 1}$ antibody could be detected. Characteristics of reactions in the $\mathrm{Pl}^{\mathrm{B} 1}$-anti- $\mathrm{Pl}^{\mathrm{B} 1}$ system are described, and certain factors that influence measurement and detection of antiplatelet antibodies are discussed.

4. One of the maternal isoantibodies could be 
measured only by its ability to block the reactions of a known complement-fixing anti-P1 ${ }^{\mathrm{A} 1}$ antibody.

\section{ACKNOWLEDGMENT}

We are indebted to Dr. William J. Harrington, Dr. Sanford Leiken and Dr. Gerald Miller for their assistance in studying two of the reported families. The technical assistance of Mrs. Winifred Biehl is greatly appreciated, and we wish to thank Mrs. Mary H. McGinniss for determining the erythrocyte phenotypes.

\section{ADDENDUM}

After this report was submitted, several isoantigens, including the antigen labeled $\mathrm{Pl}^{\mathrm{B}}$, were found to be present on granulocytes and lymphocytes, as well as on platelets. A more appropriate descriptive symbol for $\mathrm{Pl}^{\mathrm{B1}}$ would be $\mathrm{PlGrLy}{ }^{\mathrm{B} 1}$ to distinguish it from antigens limited to one cell type. The report which describes an additional shared antigen, $\mathrm{PlGrLy}^{\mathrm{C} 1}$, and an antigen limited to lymphocytes, $\mathrm{Ly}^{\mathrm{D} 1}$, and explains the induction of only thrombocytopenia in infants exposed to antibodies against antigens shared by platelets and leukocytes, will appear shortly (28). The antigen $\mathrm{Pl}^{\mathrm{\Delta 1}}$ is on platelets only.

\section{REFERENCES}

1. Harrington, W. J., Sprague, C. C., Minnich, V., Moore, C. V., Aulvin, R. C., and Dubach, R. Immunologic mechanisms in idiopathic and neonatal thrombocytopenic purpura. Ann. intern. Med. 1953, 38, 433.

2. Schulman, I., Smith, C. H., and Ando, R. E. Congenital thrombocytopenic purpura: Observations on three infants born of a non-affected mother; demonstration of platelet agglutinins and evidence for platelet isoimmunization (abstract). A. M. A. J. Dis. Child. 1954, 88, 784.

3. Moulinier, J. Iso-immunisation maternelle antiplaquettaire et purpura néo-natal. Le système de groupe plaquettaire "duzo." Trans. 6th Congress of European Society of Haematology, 1957. Basel, Karger, 1958, Part 2, p. S817.

4. Shulman, N. R. Immunoreactions involving platelets. I. A steric and kinetic model for formation of a complex from a human antibody, quinidine as a haptene, and platelets; and for fixation of complement by the complex. J. exp. Med. 1958, 107, 665 .

5. Shulman, N. R. Immunoreactions involving platelets. III. Quantitative aspects of platelet agglutination, inhibition of clot retraction, and other reactions caused by the antibody of quinidine purpura. J. exp. Med. 1958, 107, 697.

6. Shulman, N. R., Aster, R. H., Leitner, A., and Hiller, M. C. Immunoreactions involving platelets. V. Post-transfusion purpura due to a complementfixing antibody against a genetically controlled platelet antigen. A proposed mechanism for throm- bocytopenia and its relevance in "autoimmunity." J. clin. Invest. 1961, 40, 1597.

7. van Loghem, J. J., Jr., Dorfmeijer, H., van der Hart, M., and Schrender, F. Serological and genetical studies on a platelet antigen ( $\mathrm{Zw})$. Vox Sang. (Basel) 1959, 4, 161.

8. Dausset, J. Normal and pathological platelet agglutinins investigated by means of the shaking method. Vox Sang. (Amsterdam) 1954, 4, 204.

9. Stefanini, M., Plitman, G. I., Dameshek, W., Chatterjea, J. B., and Mednicoff, I. B. Studies on platelets. XI. Antigenicity of platelets and evidence of platelet groups and types in man. J. Lab. clin. Med. 1953, 42, 723.

10. Chalmers, D. G., Coombs, R. R. A., Gurner, B. W., and Dausset, $J$. The mixed antiglobulin reaction in the detection of human iso-antibodies against leucocytes, platelets and hela cells. Brit. J. Haemat. 1959, 5, 225.

11. Kissmeyer-Nielsen, F. Demonstration of platelet antibodies by haemagglutination of antigen coated tanned erythrocytes. Vox Sang. (Amsterdam) 1953, 3, 123.

12. Stern, C. Principles of Human Genetics. San Francisco, Freeman, 1950, p. 152.

13. Mahon, R., Moulinier, J., Cantorné, G., and Lassalle, G. Purpura habituel du nouveau-né par incompatibilité foeto-maternelle antiplaquettaire. Gynéc. et Obstét. 1957, 56, 517.

14. Garrett, J. V., Giles, H. McC., Coombs, R. R. A., and Gurner, B. W. Neonatal purpura with platelet isoantibody in maternal serum. Lancet 1960, 1, 521.

15. Akerren, Y., and Reinand, T. Thrombocytopenia in the new-born period. Acta med. scand. 1950, suppl. 246, 281.

16. Kaplan, E. Congenital and neonatal thrombocytopenic purpura. A review. J. Pediat. 1959, 54, 644.

17. Bluestone, S. S., and Maslow, H. L. Essential thrombocytopenic purpura in the newborn infant. Report of first case treated by splenectomy. Pediatrics 1949, 4, 620.

18. Hugh-Jones, K., Manfield, P. A., and Brewer, H. F. Congenital thrombocytopenic purpura. Arch. Dis. Childh. 1960, 35, 146.

19. Shulman, N. R. Immunoreactions involving platelets. IV. Studies on the pathogenesis of thrombocytopenia in drug purpura using test doses of quinidine in sensitized individuals; their implications in idiopathic thrombocytopenic purpura. J. exp. Med. 1958, 107, 711.

20. Epstein, R. D., Lozner, E. L., Cobbey, T. S., Jr., and Davidson, C. S. Congenital thrombocytopenic purpura. Purpura hemorrhagica in pregnancy and in the newborn. Amer. J. Med. 1950, 9, 44

21. Neville, M. L., and Masterman, L. M. Neonatal thrombocytopenic purpura in two infants. Arch. Dis. Childh. 1954, 29, 163.

22. Killander, A. On the use of exchange transfusion in 
neonatal thrombocytopenic purpura; report of a case. Acta paediat. (Uppsala) 1959, 48, suppl. 117, 29.

23. Morris, M. B. Thrombocytopenic purpura in the newborn. Arch. Dis. Childh. 1954, 29, 75.

24. Randak, E. F., and Danforth, D. N. Thrombocytopenic purpura in pregnancy; report of case. Quart. Bull. Northw. Univ. med. Sch. 1951, 25, 199.

25. Vandenbroucke, J., and Verstraete, M. Thrombocytopenia due to platelet agglutinins in the newborn. Lancet 1955, 1, 593.
26. Bridges, J. M., and Carré, I. J. Congenital thrombocytopenic purpura treated by exchange transfusion. Arch. Dis. Childh. 1961, 36, 210.

27. de Nicola, P., Rosti, P., and Zangaglia, O. Complement fixation test due to the interaction of specific antiplatelet serum and heterologous platelet antigen. J. Lab. clin. Med. 1955, 45, 725.

28. Shulman, N. R., Marder, V. J., Aledort, L. M., and Hiller, M. C. Complement-fixing isoantibodies against antigens common to platelets and leukocytes. Trans. Ass. Amer. Phycns 1962. In press.

\section{IMPORTANT NOTICE}

THE EDITORIAL AND BUSINESS OFFICES OF

THE JOURNAL OF CLINICAL INVESTIGATION

WILL MOVE ON

MAY 1,1962

OLD ADDRESS: THE JOURNAL OF CLINICAL INVESTIGATION

333 CEDAR STREET

NEW HAVEN 11, CONNECTICUT

NEW ADDRESS: THE JOURNAL OF CLINICAL INVESTIGATION

10 STOUGHTON STREET

BOSTON 18, MASSACHUSETTS 